\title{
Gezondheidsverschillen voorbij
}

\section{Complexe ongelijkheid is een zaak van ons allemaal}

\author{
Jet Bussemaker · Tim 'S Jongers · Robert Vonk
}

Geaccepteerd op: 18 December 2020 / Published online: 13 January 2021

(C) The Author(s) 2021

\begin{abstract}
Samenvatting Er zijn in Nederland hardnekkige gezondheidsverschillen. Decennia aan beleid hebben die niet kunnen verkleinen. De Raad voor Volksgezondheid \& Samenleving pleit voor een heroverweging van de aanpak van sociaaleconomische gezondheidsverschillen. Gezondheidsverschillen zijn niet alleen de uitkomst van ongezond gedrag, maar ook van een complexe ongelijkheid in de samenleving. Die ongelijkheid wordt in het huidige beleid onvoldoende aangepakt. De geschiedenis leert echter dat de volksgezondheid het meest profiteerde van collectieve maatregelen rondom de leefomgeving, bestaanszekerheid en onderwijs. Om gezondheidsverschillen daadwerkelijk te verkleinen, hebben we een nieuwe doorbraak nodig. We moeten op zoek naar het rioleringsstelsel van deze tijd.
\end{abstract}

Trefwoorden sociaaleconomische gezondheidsverschillen - complexe ongelijkheid · onderwijs · arbeid · wonen · gezondheidszorg

\section{Beyond health disparities Compound social inequalities as a collective responsibility}

Abstract Decades of policy aimed at reducing health disparities in the Netherlands have not yielded the

J. Bussemaker · T. 'S Jongers · R. Vonk $(\bowtie)$

Raad voor Volksgezondheid \& Samenleving, Den Haag, Nederland

ra.vonk@raadrvs.nl

\section{J. Bussemaker}

Faculteit Governance and Global Affairs, Leiden University

College, Leiden, Nederland

R. Vonk

Erasmus School for Health Policy and Management, Erasmus Universiteit Rotterdam, Rotterdam, Nederland desired result. The Council for Public Health and Society therefore argues for a new approach. Inequalities in health do not only arise because of individual unhealthy behaviour, but also by compound inequalities in society. These social inequalities are not adequately addressed by existing policies aimed at health disparities. History shows that public health benefitted the most from policy measures concerning the physical environment, livelihood security and education. In order to adequately address health disparities, we need a new breakthrough: a 'sewer system 2.0 ' for the current era.

Keywords Health disparities - Compound inequality · Education $\cdot$ Labour $\cdot$ Housing $\cdot$ Health care

\section{Inleiding}

De afgelopen anderhalve eeuw is er een enorme gezondheidswinst geboekt: per decennium kregen we er drie levensjaren bij. Bovendien brengen we deze gewonnen levensjaren veelal in goede gezondheid door. De winst is echter niet gelijk verdeeld over de bevolking, en dat begint al bij de geboorte. De gemiddelde levensverwachting van kinderen geboren in het armste segment van de bevolking ligt gemiddeld 7,5 jaar lager dan bij kinderen die worden geboren in de rijkste gezinnen van Nederland. Het verschil in levensverwachting in als goed ervaren gezondheid is nog groter: kinderen die op dit moment in de meer welgestelde milieus worden geboren leven gemiddeld meer dan 18 jaar langer in goede gezondheid dan kinderen die opgroeien in arme gezinnen [1].

Deze gezondheidsverschillen worden vaak sociaaleconomische gezondheidsverschillen genoemd. In de centrale missie van de Kennis- en Innovatieagenda voor de topsector Gezondheid en Zorg staat dat 'in 2040 (...) de gezondheidsverschillen tussen de laag- 
ste en hoogste sociaaleconomische groepen met $30 \%$ (moeten zijn) afgenomen' [2]. Dit is een streven dat de Raad voor Volksgezondheid \& Samenleving volledig onderschrijft. De vraag is echter: halen we dit doel als we alleen het huidige beleid voortzetten? Ondanks alle beleidsmaatregelen die de afgelopen decennia uitgevoerd zijn om de sociaaleconomische gezondheidsverschillen te verkleinen, hebben die inspanningen niet tot het gewenste resultaat geleid [3].

De vraag dringt zich op of het huidige beleid zich wel op de juiste zaken concentreert. Met dit artikel willen we een lans breken voor een bredere kijk op gezondheidsverschillen en de achterliggende oorzaken die deze in stand houden. Dit vraagt om een bredere aanpak, waarbij de verbinding wordt gezocht met welzijn, wonen, leefomgeving en onderwijs. Deze aanpak krijgt nu vooral op lokaal niveau vorm, maar het aanpakken van de causes of the causes, zoals de Britse arts Michael Marmot het ooit noemde, is een zaak van ons allemaal [4].

\section{Complexe ongelijkheid als maatschappelijk probleem}

Achter gezondheidsverschillen gaat een complexe ongelijkheid schuil. Onze gezondheid wordt immers voor een belangrijk deel bepaald door de omstandigheden waarin we worden geboren, opgroeien, wonen, werken en oud worden. Als individu hebben we niet altijd de mogelijkheid om die factoren te beïnvloeden. Bovendien is er vaak sprake van een stapeling en interactie van factoren, zoals bestaansonzekerheid én een precaire huisvesting. Of schulden én een instabiele gezinssituatie, laaggeletterdheid én het hebben van een migratieachtergrond. Of een migratiegeschiedenis én discriminatie. Hoe meer we ons geconfronteerd zien met een opeenstapeling van problemen, die elkaar ook nog eens beïnvloeden, des te kleiner ons vermogen om ze zelf te verhelpen en hoe groter het effect op onze gezondheid [5].

Een aanzienlijk deel van de bevolking wordt geconfronteerd met vormen van complexe ongelijkheid. Uit cijfers van het SCP blijkt dat ongeveer $29 \%$ van de bevolking te maken heeft met (een combinatie van) tekorten in persoonlijk, cultureel, economisch en sociaal kapitaal. Dat betekent: ze hebben geen ondersteunend informeel netwerk, geen stabiele woonsituatie, geen werk, ze zijn laagopgeleid en vaak onzeker, en er zijn onvoldoende financiële middelen. Bovendien hebben ze te maken met een slechte fysieke of mentale gezondheid [6]. Een deel van de bevolking raakt op velerlei vlakken achterop.

Gezondheidsachterstanden zijn voor een substantiële groep de uitkomst van een werkelijkheid waarin verschillende factoren stapelen en met elkaar verweven zijn. Door het nationale gezondheidsbeleid vooral te richten op individuele leefstijl en gedrag wordt in feite - gechargeerd gezegd - vooral het symptoom be- streden en niet de kwaal. Dat betekent allerminst dat we met dit beleid moeten stoppen. We moeten juist meer doen. Hierbij kunnen we leren van het verleden.

\section{Historische doorbraken}

In de afgelopen 150 jaar heeft een aantal doorbraken gezorgd voor een spectaculaire toename van de levensverwachting. In de eerste plaats is dat de opkomst van stadshygiëne. De cholera-epidemieën van de negentiende eeuw maakten duidelijk dat mensen in de stad voor hun gezondheid sterk van elkaar afhankelijk waren. Doordat iedereen hetzelfde grondof oppervlaktewater gebruikte als bron van drinkwater, maar ook om huisvuil en fecaliën af te voeren, kon cholera zich eenvoudig verspreiden, zowel in de arme als in de rijke wijken. Cholera werd daardoor een gemeenschappelijk probleem dat alleen kon worden opgelost door gemeenschappelijke maatregelen: riolering, drinkwaterleidingen en huisvuilverwijdering.

Een tweede belangrijke doorbraak is de invoering van sociale wetgeving aan het begin van de twintigste eeuw. De industrialisering van Nederland ging gepaard met steeds slechter wordende arbeids- en leefomstandigheden, en toenemende sociale spanningen. Langzaam drong het besef door dat (financiële) bestaansonzekerheid als gevolg van arbeidsongevallen, invaliditeit, ouderdom, werkloosheid en ziekte niet meer konden worden afgedaan als individuele risico's. Alleen door een collectieve aanpak kon worden voorkomen dat de gevolgen van tegenslag en bestaansonzekerheid van een deel van de samenleving over zouden slaan op de samenleving als geheel. Deze ontwikkeling zette door in de jaren vijftig van de vorige eeuw, toen politieke en maatschappelijke stabiliteit noodzakelijk waren voor de wederopbouw van de samenleving. Stukje bij beetje werd de verzorgingsstaat 'van de wieg tot het graf' opgebouwd.

In dezelfde periode werd de maatschappelijke ongelijkheid verder verkleind door het onderwijs. Stoppen met de lagere school was eerder uitzondering dan regel voor de generatie die na de Tweede Wereldoorlog geboren werd. Onderwijs werd hierdoor dé emancipatiemachine en het aantal hoogopgeleiden neemt sindsdien almaar toe. Dit zorgde voor een stijgend welvaartsniveau en een nooit eerder voorgekomen sociale mobiliteit. Het positieve effect daarvan op onze gezondheid was spectaculair.

Geen van deze doorbraken had een langere levensverwachting als doel, die was als het ware een positief neveneffect ervan. Het welbegrepen eigenbelang, maar ook de collectieve insteek van de maatregelen, kwamen ieders gezondheid ten goede.

\section{Hoe staat het er nu voor?}

Kijken naar gezondheidsverschillen is net als kijken naar sterren: je ziet het resultaat van beleid dat decennia geleden is ingezet. Dat maakt het er niet eenvou- 
diger op. Om de complexe ongelijkheid te begrijpen, richten we de blik op het recente verleden, vanaf eind jaren tachtig, toen sociaaleconomische gezondheidsverschillen op de politieke agenda kwamen. De vraag die we ons stellen is: waar kunnen we hedendaagse doorbraken zoeken?

\section{Ongelijkheid in wonen en leefomgeving groeit}

Veel steden hebben geprofiteerd van de economische groei van de jaren 1990 en 2000. Verloederde wijken konden worden opgeknapt en er kon weer worden geïnvesteerd in openbaar vervoer, groen en andere voorzieningen. Het onderzoek De verdeelde triomf (2016) van het Planbureau van de Leefomgeving laat zien dat niet iedereen in gelijke mate van die heropleving heeft geprofiteerd. Het toenemende woningtekort heeft het voor mensen met een (beneden)modaal inkomen moeilijker gemaakt om in de stad te wonen. Hierdoor ontstonden wijken en gemeenten waarin een onevenredig groot aantal mensen woont met eenzelfde sociale positie. Woningen, sportfaciliteiten en publieke voorzieningen zijn er vaak van minder goede kwaliteit. De scholen worden er door de Onderwijsinspectie als zwak tot zeer zwak bestempeld. De leefbaarheid en het veiligheidsgevoel in deze buurten en wijken nemen bovendien af.

Ongelijkheid in wonen heeft niet enkel gevolgen voor die buurten waar problemen zich dreigen op te stapelen, maar ook voor de stad zelf. In steden als Utrecht en Amsterdam worden personeelstekort bij politie, kinderopvang, onderwijs en zorg gerelateerd aan de woningnood. Deze fenomenen worden bovendien versterkt door een regionale krimp aan de randen van Nederland, waar juist hoogopgeleide jongeren wegtrekken richting de (Rand)stad. Er waren altijd al regionale verschillen, maar de maatschappelijke segregatie tussen én binnen regio's lijkt toe te nemen. Dit heeft impact op het leven van mensen en hun kansen.

\section{Bestaansonzekerheid neemt toe}

Sinds de jaren tachtig is de verzorgingsstaat vrijwel permanent in onderhoud. Tegelijkertijd heeft de overheid in veel maatschappelijke domeinen een stapje teruggezet, zijn overheidsdiensten geliberaliseerd of geprivatiseerd en kwam de focus te liggen op de eigen verantwoordelijkheid van de burger. Risico's rond inkomen, werk en gezondheid werden meer gekoppeld aan individuele verantwoordelijkheid en keuzevrijheid dan voordien. Dit leidde tot technisch gedetailleerde, maar complexe voorzieningen waarin veel mensen verdwalen. Kwetsbare jongeren lopen jeugdzorg mis; ouderen weten niet meer waar ze zorg kunnen krijgen.

Bovendien heeft de flexibeler geworden arbeidsmarkt een nieuwe kloof gecreëerd. Ook dit heeft effect op andere terreinen. Ongeveer de helft van de huurders in Nederland heeft moeite met rondkomen, $40 \%$ ervaart financiële schaarste en $30 \%$ heeft te kampen met betalingsachterstanden. Een kwart van de huurders, oftewel 800.000 huishoudens, heeft te weinig middelen om in het levensonderhoud te voorzien. Anno 2020 weten we dat een precaire woonsituatie en het hebben van een onzeker inkomen grote invloed hebben op de fysieke en mentale gezondheid van mensen. Het verdwijnen van stabiliteit in bestaanszekerheid betekent meestal achteruitgang in gezondheid.

\section{Ongelijkheid in onderwijs}

De huidige meritocratische samenleving waarin onze sociaaleconomische positie wordt bepaald door onze eigen verdiensten of persoonlijk falen, ontkent maatschappelijke invloeden. Het gezin, de straat, de wijk en de sociale omgeving waar we opgroeien leveren eveneens bijdrage aan het later (niet) behaalde succes. Ook hier versterken effecten elkaar: het lerarentekort speelt vooral in probleemwijken. Dit vergroot de kansenongelijkheid. Ironisch genoeg heeft de enorme stijging van het aantal hoogopgeleiden de waarde van een diploma doen dalen. Een mooi diploma is niet langer voldoende: vrijwilligerswerk, stages, bijbaantjes of deelname aan internationale uitwisseling worden steeds belangrijker. Dat is voor kinderen uit armere gezinnen of jonge mantelzorgers meestal onmogelijk. Over de hele breedte neemt de druk op jongeren toe: niet alleen in het onderwijs, maar ook in hun toekomstige kansen op de woning- en arbeidsmarkt. Bestaande ongelijkheid wordt daardoor nog eens uitvergroot.

\section{Op zoek naar een nieuwe doorbraak}

De geschiedenis leert dat de volksgezondheid het meest profiteerde van collectieve maatregelen die niet per definitie een betere gezondheid voor ogen hadden. Daarnaast kunnen we concluderen dat de oorzaken van (on)gezondheid dieper liggen dan in individueel gedrag. De Raad voor Volksgezondheid \& Samenleving vindt dan ook dat de term 'sociaaleconomische gezondheidsverschillen' toe is aan heroverweging. Het gaat immers om de complexe ongelijkheid achter gezondheidsverschillen. Complexe ongelijkheid gaat over de samenleving als geheel en is misschien wel dé sociale kwestie van deze tijd.

Om gezondheidsverschillen daadwerkelijk te verkleinen, moeten we vooral de achterliggende complexe ongelijkheid aan de kaak stellen. Complexe ongelijkheid gaat ten koste van onze maatschappelijke welvaart, veerkracht én onze gezondheid. Het aanpakken ervan vereist beleid voorbij het individu, dat breder kijkt dan leefstijl en persoonlijke interventies. Het vergt een nieuwe doorbraak, gericht op ons welbegrepen eigenbelang én ons gezamenlijk belang. We 
moeten op zoek naar het rioleringsstelsel van deze tijd.

We moeten bij het terugdringen van gezondheidsverschillen breder durven kijken. Niet alleen naar het individu, maar ook naar de maatschappelijke structuren en de wijze waarop deze aan ongelijkheid bijdragen. Radicale ideeën moeten daarbij op voorhand niet geschuwd worden. Want hoe veerkrachtig is een samenleving waar ruim een kwart van de bevolking bestaansonzekerheid kent? Hoe rechtvaardig is een samenleving waarbij gelijke talenten niet tot dezelfde kansen leiden? Hoe gelijkwaardig is een samenleving waarin sprake is van toenemende sociale scheidslijnen? Omdat de resultaten van interventies in complexe ongelijkheid pas decennia later zichtbaar worden, zijn een langetermijnvisie én bestuurlijk doorzettingsvermogen nodig. We moeten daarbij verder durven kijken dan één kabinetstermijn en verder dan de politieke waan van de dag. En we moeten allemaal ons steentje bijdragen - maatschappelijk middenveld, bedrijfsleven, sport, onderwijs en de individuele burger. It takes a society to fight complex inequality.

Open Access This article is licensed under a Creative Commons Attribution 4.0 International License, which permits use, sharing, adaptation, distribution and reproduction in any medium or format, as long as you give appropriate credit to the original author(s) and the source, provide a link to the Creative Commons licence, and indicate if changes were made. The images or other third party material in this article are included in the article's Creative Commons licence, unless indicated otherwise in a credit line to the material. If material is not included in the article's Creative Commons licence and your intended use is not permitted by statutory regulation or exceeds the permitted use, you will need to obtain permission directly from the copyright holder. To view a copy of this licence, visit http://creativecommons.org/licenses/by/4.0/.

\section{Literatuur}

1. Centraal Bureau voor de Statistiek. Statline. Gezonde levensverwachting; inkomensklasse. Den Haag: Bureau voor de Statistiek; 2019. Beschikbaar via: https://opendata.cbs. $\mathrm{nl} /$ statline $/ \# / \mathrm{CBS} / \mathrm{nl} /$ dataset/80298ned/table?dl=3A74F.

2. Health Holland. Kennis- en Innovatieagenda 2020-2023 voor Gezondheid \& Zorg. Utrecht: Health Holland; 2019. Beschikbaar via: https://www.health-holland.com/ public/publications/kia/kennis-en-innovatieagenda2020-2023-gezondheid-en-zorg.pdf.

3. Raad voor Volksgezondheid \& Samenleving. Gezondheidsverschillen voorbij. Complexe ongelijkheid is een zaak van ons allemaal. Den Haag: RVS; 2020. Beschikbaar via: https://adviezen.raadrvs.nl/gezondheidsverschillenvoorbij/.

4. Marmot M. The health gap: the challenge of an unequal world: the argument. IntJEpidemiol. 2017;46(4):1312-8.

5. Sociaal en Cultureel Planbureau. Verschil in Nederland. Den Haag: SCP; 2014.

6. Planbureau voor de Leefomgeving. De verdeelde triomf. Banengroei en economische ongelijkheid in de 22 stadsgewesten. Den Haag: PBL; 2016. Beschikbaar via: https://themasites.pbl.nl/o/verdeelde-triomfbanengroei-en-economische-ongelijkheid/. 